\title{
The Reform of Consumption Tax from the Perspective of Functional Orientation in the New Era of China
}

\author{
Liu yang \\ School of Accounting and Finance, Xiamen University Tan Kah Kee college, Xiamen, Fujian, China
}

469682618@qq.com

Keywords: consumption tax, tax scope, tax rate

\begin{abstract}
Consumption tax is an important auxiliary tax with multiple functions. As time goes, it can be given some new orientations: such as replacing some functions of personal income tax to improve the progressiveness of the taxation system; replacing some of the functions of business tax to implement industry regulation more effectively; making up for the defect of VAT and improving the efficiency of resource allocation; making up for the lack of local taxes and build a new pattern of income distribution among central and local governments. Reasonable expansion of the tax scope and the appropriate adjustment of tax rate will help consumption tax to better meet the requirements of the new era.
\end{abstract}

\section{Introduction}

Since China's consumption tax was formed in 1994, after more than 20 years of development and changes, its position has always been to obtain fiscal revenue, correct external economy, promote social fairness and guide consumption. In recent years, the reform of replacing business tax with VAT is being fully promoted, the ecological environment is deteriorating, the gap between the rich and the poor is gradually expanding, some "bad" consumer behaviors are being deviant and paranoid. The functioning of the consumption tax has been placed on Greater hope and higher requirements.

\section{The new position that consumption tax can be given}

\subsection{Consumption tax can replace part of the functions of Personal Income tax to improve the} progressiveness of the tax system

In recent years, there have been arguments for enhancing the progressiveness of the tax system by increasing the proportion of direct taxes (mainly personal income tax). However, in the author's opinion, taking into account the difficulties of Personal Income tax reform, in the short term, it may be more efficient to increase the proportion of consumption tax in China's tax system to achieve the same goal.

As we all know, taxation is a way of redistributing income. This redistribution can also be subdivided into secondary and tertiary distributions. Direct taxes (such as Personal income tax) progressively tax on the different levels of income that people received during the initial distribution. The purpose is to reduce people's disposable income gap and restore fairness to a certain extent. This is the second distribution of income. After income tax adjustment, people's income will be distributed a third time by indirect taxes (such as commodity taxes), that is, people will bear different commodity taxes due to the differences in consumption levels and consumption structure. In fact, the second distribution determines the individual's disposable income, but the third distributions really determine the utility of the goods that purchased with these disposable incomes. In other words, In other words, income taxes have direct impacts on the pattern of income distribution, and commodity taxes have indirect effects. [1]

According to whether the tax scope is selective, commodity tax can be divided into general merchandise tax and selective merchandise tax. And due to decreasing marginal propensity to 
consume, the general merchandise tax whose scope does not have selective (such as VAT) will produce regressive effect, that is, the tax burden will decrease with increasing income. Therefore, only selective taxation of goods based on their nature (such as consumption tax) can achieve the purpose of improving the progressiveness of the tax system.

Compared with personal income tax, consumption tax has an irreplaceable advantage in improving the progressiveness of the tax system.

\subsubsection{Consumption tax system is Simple and course difficulty is low}

The complexity of the tax system should also be compatible with the socioeconomic conditions of developing countries. Overly complex taxation systems generate excessive costs in the collection process, which greatly reduces the cumulative effect of fiscal spending. Developing countries should obtain sufficient tax revenues in a tax system that is as simple as possible. The lack of progressiveness in the expropriation process can be compensated by the progressiveness of fiscal expenditures. It is only necessary to ensure that the combination of expropriation and use is cumulative. The excise tax is more in line with this requirement. First of all, the consumption tax is generally based on the sales price or quantity of goods. The tax base is easy to determine. Instead, personal income tax needs to measure the taxable which is more complicated; secondly, the consumption tax rate is mainly Proportion or fixed form rather than progressive tax rate. Therefore, the consumption tax is facilitated and the taxpayer's compliance costs are also low. With China's current taxation capacity, it is sufficient to obtain tax revenues at a low cost, so that it can better ensure the progressiveness of the follow-up fiscal expenditure.

\subsubsection{The underground economy can be included in the scope of consumption tax}

Corporate income tax and personal income tax are difficult to tax the underground economy, which is the biggest difficulty of income tax. While the consumption tax is different, due to the existence of tax transfer, income from the underground economy will also be included in the scope of adjustment at the time of consumption, so the tax coverage is wider. [2]In this respect, the actual adjustment effect of the consumption tax on the income gap may even be stronger than income tax.

\subsubsection{The consumption tax is more hidden}

Consumption tax is an indirect tax. It indirectly tax on the goods that are circulated, rather than taxpayers' income. The tax pain is less. In addition, the current excise tax is levied on production, commissioned processing, and import, rather than the retail level. Consumers are not aware of this. Therefore, the consumption tax is more subtle than the income tax, the tax burden is small, and there is more room for adjustment.

\subsubsection{The method of collection is mature and efficient}

The coverage of personal income tax in China is relatively narrow, and the reform of the taxation model will bring great pressure on tax collection and administration. It will take a long time to increase the proportion of personal income tax. Therefore, it is more sensible to expand the scope of consumption tax which is more efficient to replace part of the functions of personal income tax in the aspect of fairness.

\subsection{The past business tax in China has adopted different tax rates for different industries in order to regulate the industry.}

After the full implementation of replacing business tax with VAT, the business tax was withdrawn from the historical stage, but the business tax control function could not be completely inherited by VAT. As a neutral tax, reducing the tax rate and even achieving a single tax rate is the future direction of VAT. Therefore, the function of implementing industry regulation through circulation taxes can only be "refilled" by consumption tax. [3]

\subsection{Consumption tax can make up for the lack of VAT and improve resource allocation efficiency}

Consumption tax has always been a necessary supplementary tax for VAT. As mentioned above, the neutral positioning of VAT makes it difficult to take into account the leverage of taxation. When the market value law is effective, the neutral characteristic of VAT can fully reduce the efficiency loss (excessive burden) arising from taxation. However, when the law of market value is invalid or 
inefficient, the neutral VAT cannot guide the reconfiguration of resources. For example, in the environmental protection field, goods with negative externalities must be taxed in addition to VAT to reduce the gap between their private and social costs, thereby pushing down the yield that overestimated by market, and then re-allocation of resources to the fields where the yield is higher. The consumption tax just can do this very well, and the more external cost goods are taxed by the consumption tax, the more obvious the function of improving resource allocation efficiency.

\subsection{Consumption tax can make up for the lack of local taxes and build a new pattern of income distribution among central and local governments}

Although the VAT revenue distribution ratio in China after the change of business tax to VAT has ensured that local financial resources are basically unchanged. But the construction of the local tax system cannot simply consider how much the tax revenue increases or decreases. It should be based on the nature and function of the taxes, considering the central government and Division of authority and financial power between local governments. The consumption tax is currently a central tax and there has been controversy over its income distribution. Some scholars believe that the consumption tax has a macro-control function and a regulation distribution function. For example, the taxation of products with negative externalities has the characteristic of non-benefits taxation. Therefore, a more reasonable approach is imposed by the central government. (Li Sheng, Ning Chao, et al., 2017). However, some scholars suggested that we should draw lessons from the United States' practice and regard consumption tax as a local tax to make up for the inadequacies of the local tax system (Guo Qingwang, Lv Bingyang, et al., 2014).

The author believes that the existence of such controversy is precisely due to the fact that consumption tax has regulatory and fair functions which are related to the overall situation in one hand, and some taxable consumer goods such as bad consumer goods and negative external products also have certain regional characteristics on the other hand. Therefore, consumption tax can be used as a central and local sharing tax. The way of sharing can refer to business tax practices, that is, dividing the tax base by industry. There are some commodities that have the ability of macro-control, and there are big differences in production among different regions. If the consumption tax levied on these commodities is regarded as the income of local governments, the income of these governments will be too different, so the consumption tax of these commodities should be a central tax. On the contrary, the consumption tax which levied on goods with certain local characteristics are more suitable be local taxes. However, from the current scope of consumption taxes in China, there are fewer types of goods that can be attributed to local taxes. If the consumption tax is allowed to support a part of the local fiscal revenue system, and at the same time avoiding the central government's fiscal downturn, it is necessary to expand the taxation scope of the consumption tax or raise the overall tax rate.

\section{Pursue consumption tax reform based on its new orientations}

\subsection{Extending the scope of consumption tax}

The current adjustment effect of China's consumption tax is not yet significant. One of the reasons is that its scope is still relatively narrow and its tax base is relatively small. According to the scope of the curriculum, consumption tax can be divided into three types: limited type, intermediate type, and extended type. There are 15 kinds of commodities that are currently subject to consumption tax in China, which still belongs to the limited type. In the world, more and more countries are moving from limited type to intermediate type or from intermediate type to extended one. The scope of China's consumption tax levy should also be readjusted in accordance with international trends, expand the scope of taxation, and give better play to the function of the adjustment.

\subsubsection{Luxury goods}

As mentioned earlier, consumption tax originally had the ability to replace some of the fair functions of personal income tax, that is, to improve the progressiveness of the tax system by taxing luxury goods. However, the premise of this progressive play is that the scope of consumption 
taxation is reasonable. If there are too few luxury categories to be taxed, the progressive effect cannot be guaranteed. Zhang Nan and Peng Hai bin (2018) used microscopic simulation methods to measure the indirect tax burden of Chinese families in 2012. One of the conclusions was that the consumption tax MT index was negative, indicating that the consumption tax played a negative regulatory role in redistribution. [4]

One of the reasons is that there are too few luxury categories with consumption tax levied. Therefore, we can choose luxury goods with high income elasticity, low price elasticity and even positive prices to be included in the taxation scope of consumption tax. Such as: private jets, high-priced artworks, luxury furniture and so on. Of course, improving the progressiveness of consumption tax does not mean blind expansion. It should also reduce or even eliminate the consumption tax on some taxable consumer goods that have become necessities. For example, in the current consumption tax line, the "car" tariff can be changed to " "Luxury car" (similar to advanced watches and high-end cosmetics). This is what Australia does. The Federal Government of Australia imposes a luxury car tax on luxury cars that contain after-tax prices for goods and services.

\subsubsection{Service}

As mentioned earlier, after the disappearance of China's business tax, the original industrial tax adjustment function of the business tax must be inherited by consumption tax. However, at present, the taxation scope of China's consumption tax is limited to some goods and does not involve services. This situation lags behind international practices. For example, South Korea included the golf course in the scope of taxation, and Japan separately levies golf course use tax and bathing tax. [5] In China, the scope of consumption tax includes only golf balls and golf equipment. As another example, according to the definitions of the European Commission, the International Energy Agency, and the OECD, roads and transportation services also belong to the environment-related tax base. In reality, the federal government of the United States imposes excise taxes on freeway traffic and Japan levies consumption taxes on local roads. However, our country is also limited to taxable consumer goods such as fuel and automobiles. Therefore, the excise tax that wants to assume the business tax control function of the business tax must expand the scope of taxation to some service industries, especially the high-end service industry. Such as: club services, high-end tourism, high-end restaurants, high-end wedding services, private custom and so on.

\subsubsection{High pollution, high energy consumption, and resource-based products}

At present, China's consumption tax covers a small number of negative external goods, including automobiles, petroleum products, firecrackers, solid wood floor, wooden disposable chopsticks, batteries, and paints. It is not enough to meet the requirements of consumption tax to make up for market defects and improve the efficiency of resource allocation. We can consider the inclusion of disposable plastic packaging, paper products, harmful pesticides, and chemical fertilizers into the scope of consumption tax.

\subsection{Adjust the tax rate of consumption tax}

\subsubsection{The tax rate of cigarettes}

China currently adopts a combination of proportional tax rate and fixed tax rate when levying consumption tax on cigarettes. Among them, the fixed tax rate is 150 yuan per case (250 pieces), and the proportional tax rate is divided into two types of cigarettes (A and B) according to the allocated price, and the tax rates are $56 \%$ and $36 \%$ respectively. The form of the fixed rate tax itself is not conducive to fairness, because in this form of tax rate, the higher the price is, the lighter the tax burden will be, so that the tax burden on the cheap cigarettes will be higher than the expensive one. In turn, the actual tax burden on cheap cigarettes consumers, the low-income group, is actually greater than the high-income earners. However, the fixed tax rate at the expense of the fairness does not necessarily have the effect of limiting the consumption of low-priced cigarettes, because a fixed amount of a box of 0.06 yuan has a limited impact on prices. The restriction on low-priced cigarettes can be completely achieved by increasing the proportional tax rate of B-type cigarettes. 


\subsubsection{High-grade cosmetics tax rate}

On October 1, 2016, our country changed its cosmetics tax title to high-end cosmetics, and reduced the tax rate from $30 \%$ to $15 \%$. The author believes that this move weakens the progressiveness of high-end cosmetics consumption tax and is not conducive to the fair function of consumption tax. What's more, due to the strong preference of high-end cosmetics consumers, the price elasticity of high-end cosmetics is lower than other luxury goods. Merchants with reduced tax burdens will not necessarily choose to lower prices. In other words, although we sacrifice the fairness and tax revenue as the cost, it does not necessarily achieve the effect of concessions to consumers, but let profit to the business.

3.2.3 Tax rate of high-pollution, high-energy-consumption, resource-based taxable consumer goods The tax rate for negative external goods such as refined oil, wooden disposable chopsticks and solid wood flooring is low. Take refined oil as an example. According to the statistics of the OECD special report "Consumption Tax Trends 2014", the tax burden of unleaded gasoline consumption tax and turnover tax taxes (VAT and consumption tax) in the relevant countries were calculated, as shown in Table 1. Among them, "consumption tax burden" is the ratio of consumption tax to retail price of gasoline. The total turnover tax burden is the ratio of the sum of VAT and consumption tax to the retail price of gasoline; the percentage of consumption tax is the ratio of consumption tax to the sum of VAT and consumption tax.

Table 1. Some of OECD countries' consumption tax and turnover tax statistics

\begin{tabular}{|c|c|c|c|}
\hline country & $\begin{array}{l}\text { consumption tax } \\
\text { burden }[\%]\end{array}$ & $\begin{array}{l}\text { total turnover tax } \\
\text { burden }[\%]\end{array}$ & $\begin{array}{c}\text { the percentage of } \\
\text { consumption tax }[\%]\end{array}$ \\
\hline Japan & 34.97 & 40.03 & 87.36 \\
\hline Korea & 35.32 & 44.66 & 79.09 \\
\hline new Zealand & 29.28 & 42.07 & 69.60 \\
\hline France & 40.91 & 57.76 & 70.83 \\
\hline Germany & 42.03 & 58.08 & 72.36 \\
\hline United Kingdom & 44.61 & 61.05 & 73.07 \\
\hline Spain & 33.33 & 50.56 & 65.93 \\
\hline Netherlands & 44.64 & 61.93 & 72.09 \\
\hline Sweden & 37.79 & 58.04 & 65.11 \\
\hline Chile & 32.28 & 42.87 & 75.29 \\
\hline Slovakia & 34.87 & 51.79 & 67.33 \\
\hline
\end{tabular}

Source: OECD. Consumption Tax Trends 2014

From the above table, it can be seen that in most countries, the level of consumption tax burden fluctuates between $30 \%$ and $45 \%$, while the total turnover tax burden fluctuates between $40 \%$ and $60 \%$. The proportion of consumption tax in turnover tax is stable between $65 \%$ and $80 \%$.

Taking the retail price of Beijing 92\# gasoline as an example, we selected three time points to analyze China's gasoline consumption tax and turnover tax burden, which were December 31, 2013 (consistent with the data collection time in Table 1) and April 31, 2018(before China's VAT tax reduction, the VAT rate for gasoline is 17\%) and May 1, 2018 (after China's VAT reduction, the VAT tax rate for gasoline is $16 \%$ ). The results are shown in the table below.

Table 2. China's gasoline consumption tax and turnover tax burden statistics in three periods

\begin{tabular}{|c|c|c|c|}
\hline & $\begin{array}{c}\text { December } \\
31,2013\end{array}$ & $\begin{array}{c}\text { April 31, } \\
2018\end{array}$ & $\begin{array}{c}\text { May 1, } \\
2018\end{array}$ \\
\hline the retail price of gasoline $[$ yuan/l] & 7.81 & 7.13 & 7.13 \\
\hline VAT $[$ yuan/l] & 1.13 & 1.04 & 0.98 \\
\hline Consumption tax $[$ yuan/l] & 1.0 & 1.52 & 1.52 \\
\hline $\begin{array}{l}\text { Urban construction tax, education surcharge, local education } \\
\text { surcharge [yuan/l] }\end{array}$ & 0.26 & 0.31 & 0.3 \\
\hline total turnover tax $[$ yuan/l] & 2.39 & 2.87 & 2.8 \\
\hline consumption tax burden & $12.80 \%$ & $21.32 \%$ & $21.32 \%$ \\
\hline total turnover tax burden & $30.6 \%$ & $40.25 \%$ & $39.27 \%$ \\
\hline the percentage of consumption tax & $41.84 \%$ & $52.96 \%$ & $54.29 \%$ \\
\hline
\end{tabular}


Source: Gasoline Retail Price comes from cngold.org. Other tax data are calculated by the author based on the relevant provisions of the tax law. VAT in the table $=$ gasoline retail price $\times$ VAT rate $/$ $(1+$ VAT rate $)$, consumption tax revenue $=$ consumption tax $/$ retail price of gasoline, total turnover tax $=$ total turnover tax amount in the table / gasoline retail price.

It can be seen that China's consumption tax burden and the total tax burden of circulation taxes at the three time points are significantly lower than other countries in the table, and the ratio of consumption tax to turnover tax is also lower than other countries. This shows that raising the tax burden on gasoline can focus on consumption tax. Since China's VAT reforms were implemented on May 1 this year, the VAT of gasoline has been further reduced. Therefore, it is even more necessary to balance the tax burden by increasing the consumption tax. At the same time, it is also adapting to increasingly stringent international resource conservation and environmental protection standards.

In addition to refined oil, other high-pollution, high-energy-consuming, resource-based taxable consumer goods such as solid wood flooring, wooden certain chopsticks, etc., are also generally low tax rates, the symbolism is greater than the actual significance of the phenomenon. Similar to the analysis of gasoline, the author proposes to raise the consumption tax rate for these products.

\section{Acknowledgment:}

This research was financially supported by Fujian Social Science Planning Project (Grant NO. FJ2015C157).

\section{References}

[1] Ma Yongbin, Yan Jia, Tax adjustment mechanism at different levels of income distribution, taxation and economy, vol.2, pp. 65-66, 2017.

[2] Li Wen, Progressiveness and Redistribution of Tax System in Developing Countries , Finance \& Trade Economics, vol.5, pp. 16-27,2013.

[3] Luo Changcai, Song Shengyu, The Taxation of Luxury Consumption: The Theory of Levy and the Direction of Reform, Taxation Research, vol.1, pp.29-33, 2017.

[4] Zhang Nan, Peng Haibin, The Measurement of Progressiveness and Redistribution Effect of Indirect Taxes, Finance \& Economics, vol. 1, pp.117-122, 2018.

[5] Gao Yang, Li Ping, The Characteristics of Consumption Tax in OECD Countries and Its Use for Reference, International Taxation In China, vol.5, pp.18-23, 2015.

[6] Wan Ying, Xu Chongbo, International Comparison of Product Consumption Tax Rates and Tax Levels, Contemporary Finance \& Economics, vol.2, pp. 46-51, 2016. 